\title{
Freshwater jellyfish in northern temperate lakes: Craspedacusta sowerbii in British Columbia, Canada
}

\author{
Florian Lüskow ${ }^{1,2, *}$, Pablo J. López-González ${ }^{3}$, Evgeny A. Pakhomov ${ }^{1,2,4}$ \\ ${ }^{1}$ Department of Earth, Ocean and Atmospheric Sciences, University of British Columbia, 2039-2207 Main Mall, Vancouver, \\ BC V6T 1Z4, Canada \\ ${ }^{2}$ Institute for the Oceans and Fisheries, University of British Columbia, 2202 Main Mall, Vancouver, BC V6T 1Z4, Canada \\ ${ }^{3}$ Biodiversidad y Ecología Acuática, Departamento de Zoología, Universidad de Sevilla, Avda. Reina Mercedes, 6, \\ 41012 Sevilla, Spain \\ ${ }^{4}$ Hakai Institute, PO Box 309, Heriot Bay, BC V0P 1H0, Canada
}

\begin{abstract}
Freshwater jellyfish species of the genus Craspedacusta purportedly originated from the Yangtze River catchment area, China, and have now been observed on all continents except Antarctica. Sightings of $C$. sowerbii in the Pacific regions of Canada were compiled to document some of the northernmost records of this species in the Americas. Species identification has been difficult in the past. Therefore, field collection of specimens was carried out on southern Vancouver Island. The morphology was described macro- and microscopically as well as molecularly using mitochondrial and nuclear markers. Collected hydromedusae from British Columbia (BC) did not deviate morphologically from $C$. sowerbii specimens from other continents, but molecular analyses support the idea of 2 main widely distributed lineages hidden under similar morphological features (i.e. a species complex). Through a community science approach, an understanding of the extent of $C$. sowerbii distribution in western and southern BC (present in 24 lakes from as early as 1990) has been established. Results showed that the number of sightings increased considerably in the period after 2010. Recent increases in sightings of $C$. sowerbii in BC and worldwide could be indicative of a climate warming-related range extension or growing public awareness and/or increased observational efforts. Even after more than $120 \mathrm{yr}$ of Craspedacusta research, much about their biology and ecology remains unknown, which motivated us to compile a list of knowledge gaps based on an extensive literature survey.
\end{abstract}

KEY WORDS: Cnidaria $\cdot$ Non-indigenous $\cdot$ Invasive species $\cdot$ Medusa $\cdot$ Community science Killarney Lake

\section{INTRODUCTION}

Craspedacusta sowerbii (Lankester 1880a) is one of few freshwater jellyfish species worldwide (Jankowski et al. 2008). They purportedly originated from the Yangtze River catchment area in China (Kramp 1950). The genus Craspedacusta comprises 3-4 species, of which C. sowerbii and C. kiatingi are believed to be the only invasive species (Jankowski \& Anokhin 2019, Schifani et al. 2019). Introduction pathways to new habitats are often uncertain, but

${ }^{*}$ Corresponding author: flueskow@eoas.ubc.ca likely include larvae in holding water for fish restocking, benthic stages grown on boat hulls or transported in mud on bird feet or in digestive tracts, and (accidental) release by aquarists (Morpurgo \& Alber 2015). Craspedacusta has a metagenetic life cycle (i.e. combining seasonal sexual [medusa stage] and continuous asexual reproductive [polyp stage] stages; Folino-Rorem et al. 2016, Marchessaux \& Bejean 2020a) and is found on all continents except Antarctica (Dumont 1994, Jankowski et al. 2008). Polyps have the ability to develop a durable, chitin-covered

(C) The authors 2021. Open Access under Creative Commons by Attribution Licence. Use, distribution and reproduction are unrestricted. Authors and original publication must be credited. 
resting body (i.e. podocysts; Acker \& Muscat 1976, Bouillon \& Boero 2000), have several forms of asexual reproduction (i.e. podocysts and frustules) (Reisinger 1957), and the capability of long-term survival without sexual reproduction (Fritz et al. 2007). A threshold for polyp budding of new medusae was determined experimentally to be $21^{\circ} \mathrm{C}$ (Folino-Rorem et al. 2016). For the medusa stage, gamete development happens at a small size (diameter about $2.4 \mathrm{~mm}$ ) (Folino-Rorem et al. 2016), and maturity may be reached after 5-6 wk (Acker \& Muscat 1976, Ziser \& Burke 1984), but may take up to 18 wk or more (Viosca \& Burkenroad 1936). Differences in food supply or abiotic parameters may explain variable maturation process lengths between the 2 studies from Louisiana lakes. Craspedacusta is found in oligo- to eutrophic lentic and lotic habitats that are either natural or man-made, mainly at temperate to subtropical latitudes. There is no conclusive evidence for artificial water bodies being more frequently invaded than lakes and rivers (Duggan \& Eastwood 2012); however, C. sowerbii is mostly observed in closed environments such as quarries, ponds, and lakes.

At high water temperatures $\left(25-30^{\circ} \mathrm{C}\right)$, the medusa can grow up to $25 \mathrm{~mm}$ in diameter (Wesenberg-Lund 1939) and are frequently observed during summer and early autumn, generally in neutral to alkaline environments (Acker \& Muscat 1976). Populations of dioecious medusa species are often of one sex only, which may be the result of favourable environmental conditions for reproduction of polyps of one sex (Pennak 1956, Acker \& Muscat 1976) or may have resulted from the introduction of a single specimen that formed the base of a unisexual population. Further hypotheses addressing the phenomenon of unisexual medusa populations have been formulated in the past, but none of them has been proven yet. Community science approaches have been vital to freshwater jellyfish research, as their occurrence in nonnative habitats is, most often, sporadic and with a sudden appearance.

Currently, no comprehensive food web analysis has been performed clarifying Craspedacusta's trophic position. Generally, the impact of Craspedacusta medusae on lower trophic levels may be low, without significant food competition with or predation by fish (Dodson \& Cooper 1983, Spadinger \& Maier 1999). However, during jellyfish blooms that last for a few weeks it may be considerable, reaching $39 \%$ of the prey standing stock (Davis 1955, Jankowski \& Ratte 2000, Jankowski 2004, Jankowski et al. 2005, Smith \& Alexander 2008). Medusae prey mostly on cladocerans and cyclopoid copepods (Jan- kowski \& Ratte 2000, Boothroyd et al. 2002, Jankowski et al. 2005), supplementing their diet with insect larvae, rotifers, amphipods, nauplii, and fish eggs (Thomas 1951, Davis 1955, Spadinger \& Maier 1999, Pérez-Bote et al. 2006, Moreno-Leon \& Ortega-Rubio 2009). Craspedacusta has also been shown to kill larger prey items, such as fish larvae and large cladocerans, without ingesting them (Dodson \& Cooper 1983, Smith \& Alexander 2008). Polyps of C. sowerbii may consume fish larvae and oligochaetes ex situ (Dendy 1978). All information about feeding rates and selectivity is based on laboratory or mesocosm clearance experiments and stomach content analyses of field-collected specimens.

Because the parameterisation of gelatinous zooplankton in food web models has been simplified in the past, determination of their biochemical composition and trophic interactions is required (Lamb et al. 2019). Predators of medusae and their polyps are unknown, although crayfish Orconectes spp. have been shown to scavenge on medusae under laboratory conditions (Dodson \& Cooper 1983), and ducks and turtles have been observed to consume medusae in their natural environments (T. Peard pers. comm.). Craspedacusta is known to form short-lived blooms (i.e. a few weeks), even in the presence of high numbers of fish (Jankowski et al. 2005), while the tropical freshwater medusa Limnocnida tanganjicae is avoided by fish in Lake Tanganyika, despite being of a suitable size (Bose et al. 2019). Trophic cascade effects have been shown several times when medusae are abundant (Jankowski \& Ratte 2000, Jankowski 2004, Jankowski et al. 2005), and symbiotic interactions are rarely documented (Ludwig et al. 1979, Stanković \& Ternjej 2010, Morpurgo et al. 2021).

To date, Craspedacusta in Canadian freshwater systems has been mentioned in the scientific literature several times, but exclusively from eastern Canada, with its first occurrence in 1934 in 2 Québec lakes (Fantham \& Porter 1938). As reviewed several times for the US distribution, C. sowerbii has primarily been documented from eastern and central states, with only a few sightings west of the Rocky Mountains. In Canada, this species was recorded only in Ontario, Québec, and New Brunswick (Wiggins et al. 1957, McAlpine et al. 2002, El Moussaoui \& Beisner 2017a,b, Mychek-Londer et al. 2020). Despite this apparently restricted range, the private website on medusa sightings maintained by Terry L. Peard (http://freshwaterjellyfish.org/, accessed March 2020) shows many sightings in British Columbia (BC) between 1990 and 2019. Due to its geographic location, records of the freshwater medusae in $\mathrm{BC}$ have 
the potential to become the northernmost observations of this usually warm-temperate species in the Americas, despite several European and Asian reports from higher latitudes (e.g. Väinölä 2002, Lundberg et al. 2005, Stepanjants et al. 2009). Since the blooming of freshwater jellyfish is correlated with high summer temperatures (usually above $21^{\circ} \mathrm{C}$ ), it has been proposed that under climate warming scenarios the appearance and duration of such mass occurrences may become more frequent and prolonged (Minchin et al. 2016).

The aim of the present study was to (1) confirm the species identity of the often-overlooked freshwater jellyfish using morphological and genetic analyses for the first time in Western Canadian freshwater systems. Recent phylogenetic analyses have recovered different, widely separated lineages within the genus Craspedacusta, and at least 2 of them have been identified as C. sowerbii. Moreover, we aimed to (2) characterise its abiotic environment at the time of occurrence at one lake site. As C. sowerbii is a warm-temperate species, water parameters that allow its mass occurrence in a cold-temperate environment are of interest. Further, we aimed to (3) outline the temporal succession of $C$. sowerbii occurrences in BC over 3 decades using a community science approach, and (4) outline knowledge gaps in the ecology of this non-indigenous species through a literature survey.

\section{MATERIALS AND METHODS}

\subsection{Study site}

We used community science as an opportunity to sample freshwater jellyfish. While getting in touch with regular recreational visitors to small lakes in British Columbia (BC) who had reported past observations of jellyfish-like creatures, we received confirmation of jellyfish presence in Killarney Lake in early August 2020.

Killarney Lake $\left(48^{\circ} 31^{\prime} 41.9^{\prime \prime} \mathrm{N}, 123^{\circ} 27^{\prime} 23.9^{\prime \prime} \mathrm{W}\right)$ is a natural water body on southern Vancouver Island between the cities of Victoria and Saanich (Fig. 1). The lake (altitude of $107 \mathrm{~m}$ ) covers a surface area of about 4 ha $\left(0.04 \mathrm{~km}^{2}\right)$ and has a maximum depth of
$5 \mathrm{~m}$. Killarney Lake is a recreational area, where swimming, hiking, and cycling are permitted, but the use of motorised boats is prohibited (Ungstad 2012). Killarney Lake is located in a densely forested area dominated by conifers, while only a few fallen trees are noticed inside the lake. The shores of Killarney Lake are covered by grass and there are several water lily aggregations around the margins of the lake. Numerous smaller fish are present throughout the lake. In close proximity to the shore, the bottom substrate is predominantly sandy with plenty of smaller and bigger rocks.

\subsection{Specimen collection and environmental parameters}

Killarney Lake was visited on 23 August 2020. When spotted at the lake centre, medusae of Craspedacusta sowerbii were gently collected using dip nets and jars from near the surface. Several collected specimens $(n=22)$ were kept on a boat in jars filled with lake water until examination on shore. Within 10 min after collection, medusae were measured to the nearest $\mathrm{mm}$ (i.e. umbrella diameter) using an electronic calliper and were preserved individually in $95 \%$ ethanol for subsequent genetic analyses. Specimens were re-examined for umbrella diameter after months of fixation in ethanol to estimate shrinkage rates. Species identity was determined morphologically using keys in Jankowski (2001) and 
Jankowski \& Anokhin (2019). Two specimens were kept alive in a jar filled with lake water for approximately $20 \mathrm{~h}$ for observations and microscopy in the laboratory. Five specimens were individually fixed in $95 \%$ ethanol and deposited in the collection of the Royal British Columbia Museum in Victoria (deposit codes: 020-00027-001).

Temperature and conductivity were measured at the surface of the lake with a CON 6 sensor (Oakton Instruments), deployed at the centre of the lake from an inflatable boat. Euphotic depth was determined by deploying a $20 \mathrm{~cm}$ diameter standard Secchi disk. The $\mathrm{pH}$ was examined using a $\mathrm{pH} 11$ Economy Metre sonde (Oakton Instruments) from water samples taken at the surface and every $1 \mathrm{~m}$ to a depth of $5 \mathrm{~m}$.

\subsection{Morphological and cnidae analyses}

Two C. sowerbii specimens were kept alive in a jar with lake water and were described morphologically using a S8AP0 dissection microscope (Leica Microsystems) less than $1 \mathrm{~d}$ later in the laboratory at the University of British Columbia. After examination, both specimens were preserved in ethanol and used, together with 12 previously fixed specimens, for genetic analyses. Fragments from umbrella with tentacles of ethanol-fixed specimens were prepared using an adapted hexamethyldisilazane (HMDS) protocol, limiting the immersion of the fragments in this chemical to 3 min (Nation 1983, Braet et al. 1997, Shively \& Miller 2009). The fragments were mounted on stubs, coated with gold-palladium in a Leica ACE600, and observed with a Zeiss EVO scanning electron microscope at the General Research Services of Microscopy of the University of Seville. Squash preparations of tentacle tissue from 4 individuals were made for cnidocyst examinations. The length and width of undischarged capsules were measured using a Leica DMLB microscope with Nomarski interference contrast optics at maximum magnification, with an OPTIKA C-P20CC digital camera and the image software OPTIKA PROVIEW, following standard observation methods (Godknecht \& Tardent 1988).

\subsection{DNA extraction, PCR procedures, and phylogenetic analyses}

Total genomic DNA was extracted from 14 ethanolpreserved specimens from Killarney Lake using the E.Z.N.A. DNA kit (OmegaBiotech) following the manufacturer's instructions. The Cox1 and 16S mito- chondrial regions as well as the nuclear internal transcribed spacer (ITS) region (ITS1-5, 8S-ITS2) were sequenced as proposed by previous authors (Fritz et al. 2009, Karaouzas et al. 2015, Oualid et al. 2019) for comparative purposes. The Cox1 region was amplified using the primers dgLCO1490 5'-GGT CAA CAA ATC ATA AAG AYA TYG G-3' and dgHCO 2198 5'-TAA ACT TCA GGG TGA CCA AAR AAY CA-3' (Meyer et al. 2005), while the $16 \mathrm{~S}$ region was amplified using the primers 16S.Cunningham.F.1 mod 5'-ACG GAA TGA ACT CAA ATC ATG TAA G-3' and 16S.Cunningham.R.2 5'-TCG ACT GTT TAC CAA AAA CAT A-3' (Bridge et al. 1995). An 800 bp partial sequence of the nuclear DNA was amplified using the forward primer 5'-CCC TTT GTA CAC ACC GCC CGT CGC T-3' and the reverse primer 5'CTT TGG GCT GCA GTC CCA AGC AAC CCG ACT C-3' (Odorico \& Miller 1997). This last partial sequence included parts of the 18S rDNA and 28S rDNA, the complete ITS1 and ITS2 regions as well as the 5.8S rDNA region (Odorico \& Miller 1997, Fritz et al. 2009). Each PCR used $1 \mathrm{U}$ of MyTaq Red DNA Polymerase (Bioline), $10 \mu \mathrm{M}$ of each primer, approximately 30 ng of genomic DNA, and was brought to a final volume of $25 \mu \mathrm{l}$ with $\mathrm{H}_{2} \mathrm{O}$. Cox1 PCR was carried out using the following cycle profile: initial denaturation at $95^{\circ} \mathrm{C}$ for $1 \mathrm{~min}, 40$ cycles of denaturation at $95^{\circ} \mathrm{C}$ for $15 \mathrm{~s}$, annealing at $42^{\circ} \mathrm{C}$ for $15 \mathrm{~s}$, extension at $72^{\circ} \mathrm{C}$ for $10 \mathrm{~s}$, and a final extension at $72^{\circ} \mathrm{C}$ for $5 \mathrm{~min}$. The $16 \mathrm{~S}$ and ITS PCRs used the same cycle profile, but 58 and $60^{\circ} \mathrm{C}$ as annealing temperatures, respectively. The PCR products were purified using ExoSAP-ITTM PCR Product Cleanup Reagent (ThermoFisher Scientific) following the manufacturer's instructions before strong amplifications were sent to MACROGEN, Madrid, for sequencing in both directions.

All chromatograms were visualised and sequence pairs matched and edited using Sequencher v.4.0. The set of new sequences were assembled with homologous ones from GenBank of other Craspedacusta species. When available, sequences of the closest olindiid genera were used as an out-group in the implemented phylogenetic analyses (see relative phylogenetic placement of the genus Craspedacusta among other olindiids and other selected out-groups in Oualid et al. 2019). The alignments of the different sets of sequences were carried out using MUSCLE, as implemented in MEGA6 (Tamura et al. 2013). After alignment, the best nucleotide substitution model for each data set was selected using 'Modeltest' as implemented in MEGA6, according to Akaike's information criterion (AIC) and a hierar- 
chical likelihood ratio test (hLRT). The 16S data set (25 Craspedacusta sequences and 2 out-group sequences) had 557 positions, with a total of 101 variable and 86 parsimony-informative sites. The Cox 1 data set (43 Craspedacusta sequences and 2 outgroup sequences) had 680 positions, with a total of 220 variable and 192 parsimony-informative sites. The ITS data set sequences (80 Craspedacusta sequences and one out-group sequence) had 913 positions, with a total of 390 variable and 215 parsimonyinformative sites. The phylogenetic reconstructions were obtained applying maximum likelihood (ML) and Bayesian inference (BI) methods. The ML method was carried out in MEGA6 and was based on T92+I (16S), GTR+I (Cox1), and K2+G (ITS) models (Kimura 1980, Tamura 1992, Nei \& Kumar 2000) using the nearest neighbour interchange (NNI) heuristic method and 1000 bootstrap replications (Felsenstein 1985). The BI was carried out in MRBAYES v.3.1.2 (Huelsenbeck \& Ronquist 2001, Ronquist \& Huelsenbeck 2003), using the model GTR $+\mathrm{G}$ (lset nst=6 rates=gamma), 107 generations, and discarding $25 \%$ initial trees.

\subsection{Community science approach and literature review}

In August 2020, we started to communicate our findings from Killarney Lake via regional newspapers, television, and $\mathrm{CBC}$ radio to engage the broader public and increase the number of $C$. sowerbii sightings in 2020 as well as from previous years. We asked the voluntary observers to report the sighting site, month, and year of observation. The feedback over the next 3 mo was considerable (17 sighting reports from the public). Their observations supplemented earlier records taken from http:// freshwaterjellyfish.org/.

In addition, the numerical succession of publications on Craspedacusta biology, ecology, distribution, and systematics was investigated using a combined literature search in several databases (i.e. Web of Science and Google Scholar) using the search keyword 'Craspedacusta'; despite the fact that most literature was included, some articles (likely mostly early work) may have been overlooked. The publication year was noted as well as the life cycle stage in focus (medusa or polyp). Environmental parameters (i.e. surface temperature, $\mathrm{pH}$, dissolved oxygen, and chlorophyll a [chl a] concentration, Secchi depth, and conductivity at $20^{\circ} \mathrm{C}$ ) at the time of medusa bloom were compiled.

\section{RESULTS}

\subsection{Morphological characterisation}

A total of 22 medusae of Craspedacusta sowerbii were collected from Killarney Lake and examined to record size and morphology. No particular or distinctive aberrations were observed; therefore, if these do occur in the field, the number of observations was likely too low for them to be detected. The development of gametogenic structures was concordant with the size of the different specimens. Mean $( \pm \mathrm{SD})$ umbrella diameter was measured to be $9.7 \pm 2.5 \mathrm{~mm}$ (range: 5-17 mm). A re-examination (after 2 mo in $95 \%$ ethanol) indicated that umbrella diameters suffered a shrinkage by $31.0 \pm 13.5 \%(\mathrm{n}=17)$. Four gametogenic tissue pouch-like structures were suspended along the radial canals with 4 long perradial tentacles arising from the margin of the umbrella opposite the radial canals (Fig. 2A,B). The oral end of the manubrium was indistinctly 4-lobed, with each of the lobes divided into a larger number of folds (Fig. 2B). The tentacles were numerous (>300), organised along the umbrella edge, but with a certain trend to originate at different levels in 4 (or 5) different size classes (Figs. 2A,B \& 3A,B). The 4 perradial tentacles were distinctively longer than the others (up to $6 \mathrm{~mm}$ in length). The statocysts were numerous, visible at the proximal part of the velum, with long centripetal canals inside (Fig. 2C). The colouration of C. sowerbii gametogenic tissue in all investigated specimens from Killarney Lake was milkywhitish. A closer examination of these structures revealed that all medusae were males (Fig. 2B,D). Along the tentacles, nematocysts were grouped in patches (warts) of 3-6 capsules that were arranged in parallel in indistinctly complete rings (Fig. 3C,D). In the smaller size classes of tentacles, nematocysts were found isolated in pairs (Fig. 3B,E). Nematocyst were of the type microbasic euryteles (Fig. 3F,G), $7.46-10.18 \mu \mathrm{m}$ in length $(8.54 \pm 0.61 \mu \mathrm{m}, \mathrm{n}=80)$ and $2.57-3.61 \mu \mathrm{m}$ in width $(3.18 \pm 0.22 \mu \mathrm{m}, \mathrm{n}=80)$.

\subsection{Phylogenetic analyses}

The Cox 1 trees obtained by ML and BI showed similar topology in the main groupings (Fig. 4). The ML tree placed all British Columbia (BC) sequences obtained in this study together in a moderate to highly supported clade (bootstrap [Bts]: $85 \%$; posterior probability [PP]: 0.95). This clade is related to a series of sequences in a poor to moderately 

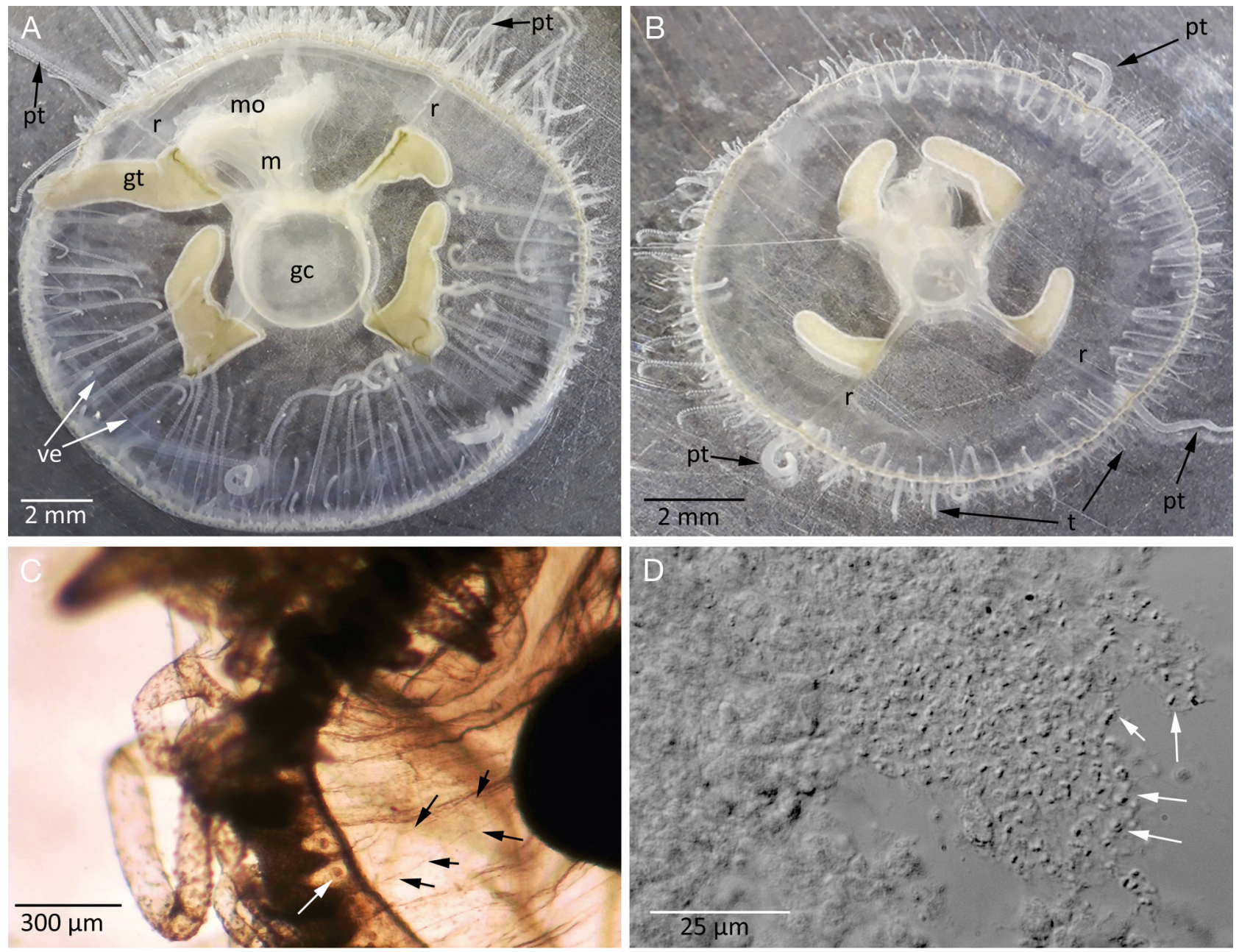

Fig. 2. Subumbrellar view of 2 Craspedacusta sowerbii medusae collected on 23 August 2020 in Killarney Lake; $($ A) diameter $=$ $17 \mathrm{~mm}$; (B) diameter $=11 \mathrm{~mm}$. (C) Detail of umbrella edge showing tentacles, statocysts (white arrow), and statocyst's centripetal canals into the velum (black arrows). (D) Spermatic cells with nearly mature sperm (white arrows). gt: gametogenic tissue pouchlike structures of male individuals; gc: gastrovascular cavity; m: manubrium; mo: manubrium opening; pt: perradial tentacle; r: radial canal; t: tentacle; ve: velum

supported polytomy (Bts: $67 \%$ ), including sequences from Chile, Italy (Sicily), and a more divergent sequence from India ( $p$-distance $3.5 \%$ from $\mathrm{BC}, 3.1 \%$ from Italian, and $2.8 \%$ from Chilean sequences). This group of sequences is included in a well-supported clade (Bts: 100\%) with a sequence from China (Hubei province) and another from Greece. The genetic distance between these 2 last sequences (China-Greece) is $0.9 \%$. These Chinese-Greek sequences are $2.1-2.4 \%$ distant from Chilean sequences, $2.7-3.0 \%$ from BC, but $4.9-5.6 \%$ from Indian sequences (Fig. 4). Furthermore, a Switzerland sequence forms a poorly supported clade (Bts: $32 \%$ ) with a subclade (Bts: 98\%) formed by Chinese (Sichuan province), Moroccan, and German sequences. Internal genetic distances in this last subclade are $0.0-0.3 \%$. This Chinese-MoroccanGerman subclade is $13.6 \%$ distant from the Switzerland sequence, and $17.4 \%$ from the BC-ChileanItalian-Indian-Chinese/Hubei-Greek assemblage. BI (Fig. 4) showed a basal polytomy with the 3 main lineages: (1) Canada/BC-Chile-Italy-India related to China/Hubei-Greece, (2) Switzerland, and (3) Morocco-Germany-China/Sichuan. Few differences between the trees obtained by ML and BI are found (see Fig. 4).

The $16 \mathrm{~S}$ trees obtained by ML and BI showed similar topology in the main groupings (Fig. S1 in Supplement 1 at www.int-res.com/articles/suppl/b030 p069_supp1.pdf). In the ML phylogeny, the specimens sequenced from $\mathrm{BC}$ belong to the same clone of other North and South American sequences that 

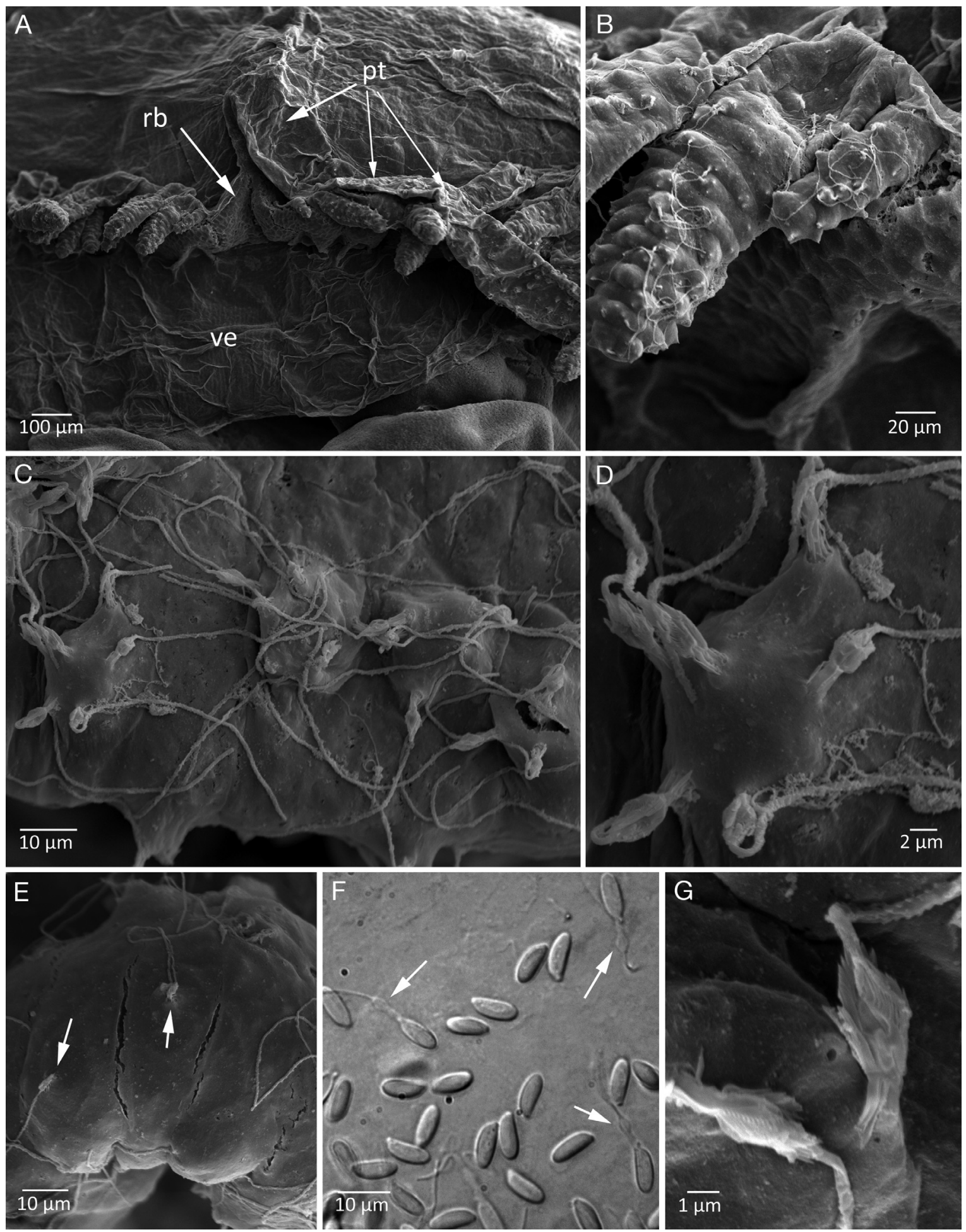

Fig. 3. (A) Scanning electron microscope (SEM) image of Craspedacusta sowerbii umbrella edge showing tentacles of different orders, one of the perradial tentacles (pt) associated with one of the radial canals and its cleft-like radial bay (rb), and the velum (ve). (B) SEM detail of tentacles of the latest order, in which the placement of the nematocysts (some of them discharged) are visible. (C) Surface of a tentacle of the first order showing warts with a set of 3-6 discharged nematocysts; SEM. (D) Detail from (C); SEM. (E) Surface of a tentacle from one of the oldest orders showing isolated discharged nematocysts; SEM. (F) Light microscope image showing discharged (white arrows) and undischarged nematocysts. (G) SEM detail of basal shaft and thread of 2 nematocysts (microbasic eurytele) 

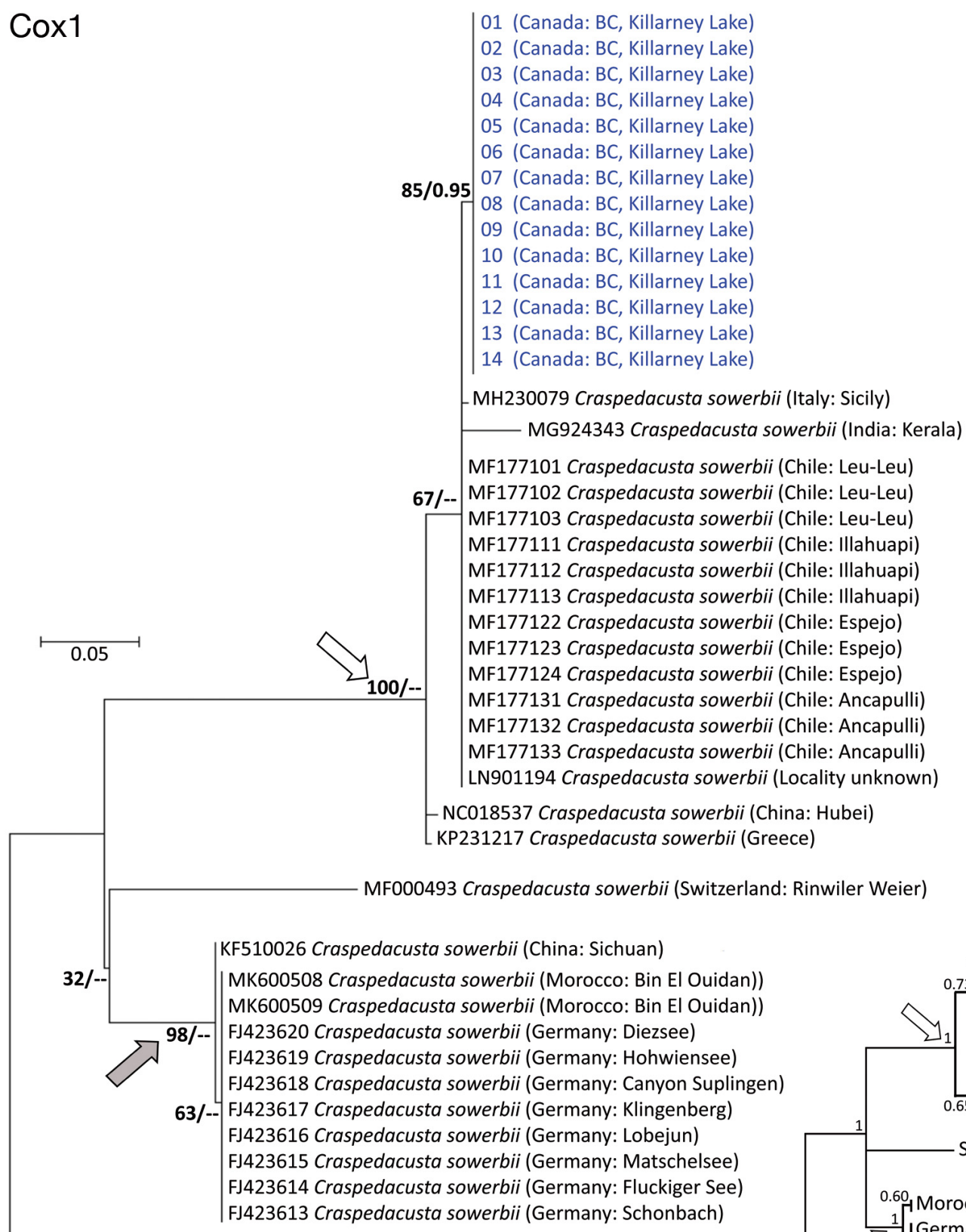

AF383927 Maeotias marginata 100/1 AF383926 Maeotias marginata

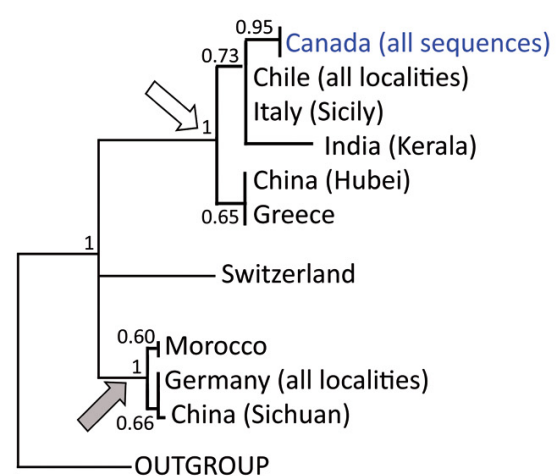

Fig. 4. Molecular analysis by maximum likelihood method. Relationships of known Cox1 sequences of Craspedacusta species using the olindiid Maeotias marginata as the out-group. The tree is drawn to scale, with branch lengths measured in the number of substitutions per site. White and grey arrows: clades with slightly different topologies obtained by Bayesian inference (see schematic tree at the bottom right). British Columbia (BC) sequences are shown in blue. GenBank accession numbers and geography (country: locality) are indicated for each sequence. Supported values of the nodes (bootstrap/posterior probability) are shown in the main tree, only posterior probability in the schematic tree; (-) clade not supported by Bayesian method

is also related to a sequence from Wuhan (Hubei Province, China). The American-Chinese clade (Bts: $100 \%$ ) is the sister group of a European-North African clade (Bts: 100\%). Sequenced specimens in both clades were identified by the authorships of the GenBank sequences as $C$. sowerbii. The whole C. sowerbii species complex (Bts: 99\%) is the sister group of a moderately supported clade formed by 2 other Craspedacusta species (C. sinensis and $C$. ziguiensis; Bts: $53 \%$ ). The uncorrected $p$-distance 
between the $\mathrm{BC}$ and other American sequences (Eastern USA and Uruguay) is $0.0 \%$. The genetic distance between American sequences and the Wuhan sequence is $0.8 \%$. The American-Chinese clade shows a $5.0 \%$ genetic distance from the European-North African clade, which is similar to the distance between 2 other Craspedacusta species recorded only in China ( $p$-distance between $C$. sinensis and C. ziguiensis: 6.2\%). Finally, the genetic distances between the $\mathrm{BC}$ specimens and Chinese species are $7.7 \%$ (to $C$. ziguiensis) and $9.1 \%$ (to $C$. sinensis). BI (Fig. S1) showed a basal polytomy with 3 main lineages: (1) Canada/BC-USA-UruguayChina/Hubei, (2) Morocco-Switzerland, and (3) $C$. ziguiensis-C. sinensis. Few differences between the trees obtained by ML and BI are found (see Fig. S1).

The ITS phylogenies obtained by ML and BI also showed a similar topology in the main groupings (Fig. S2 in Supplement 1). These analyses included a higher number of sequences, most of which were attributed to C. sowerbii. In the phylogeny based on ML (Fig. S2), a large, poorly supported polytomy gathered all BC sequences with Italian (Sicily), Chilean, and Chinese sequences (including all those identified as $C$. xinyangensis). Another poorly supported clade (Bts: $44 \%$ ) showed 2 well supported sister groups. In the first group (Bts: 99\%), there are 2 subclades; the first one including North African, German, and Chinese sequences (also including all those identified as C. kiatingi and C. sichuanensis) is highly supported (Bts. 98\%), and the other subclade included the only sequence attributed to the Chinese species $C$. ziguiensis. In the sister group of that large clade (C. sowerbii [including C. kiatingi and C. sichuanensis]-C. ziguiensis), all sequences of $C$. sinensis (including the single available sequence attributed to C. brevinema) can be found, with strong support (Bts: $99 \%)$. Sequences along the large basal polytomy (Canada/BC-Italy-China) have genetic distances (uncorrected $p$-distances) between 0.0 and $1.3 \%$. This last set of sequences (where specimens from BC are included) is $11.3-12.9 \%$ genetically distant from the North Africa-Germany-China clade, 11.6$13.1 \%$ from the C. ziguiensis sequence, and 17.1$19.7 \%$ from the C. sinensis clade. The C. ziguiensis sequence is $4.9-5.1 \%$ distant from the North AfricanGerman-Chinese C. sowerbii clade and 21.7-23.5\% from the C. sinensis clade. This last species, C. sinensis, is $20.4-22.7 \%$ distant from the African-GermanChinese $C$. sowerbii clade. The tree obtained by BI (Fig. S2) showed similar topology to ML, with only slight differences in the arrangement of the different C. sinensis sequences (Fig. S2).
As all BC sequenced individuals presented the same haplotype in the 3 markers examined, the sequences (Cox1, 16S, and ITS region) of a single specimen have been deposited in GenBank under accession numbers MW600236 (Cox1), MW603820 (16S), and MW603819 (ITS).

\subsection{Abiotic environment and occurrence of Craspedacusta in Killarney Lake}

On 2 August 2020, a close inspection of Killarney Lake by a volunteer observer did not reveal any jellyfish sightings, but when it was searched on 9 August, many medusae were spotted. On the sampling day (23 August 2020), numerous medusae were seen throughout the sunlit lake, predominantly concentrated in its central part (Fig. 1). While individuals were sampled at or near the surface, medusae were visually detected down to about $1 \mathrm{~m}$. At present, however, there is no detailed information on the vertical or horizontal distributions and no abundance estimates of C. sowerbii in Killarney Lake.

In Killarney Lake, the medusa stage of $C$. sowerbii was observed in several years between 2012 and 2019, and on 9 August for the first time in 2020. The sampling day at the lake was not overcast with almost complete lull conditions, which facilitated successful medusa sampling between 13:00 and 17:00 h (local time). Killarney Lake water was clear with an estimated Secchi depth of $2.8 \mathrm{~m}$. Temperature and conductivity at the surface were $24.1^{\circ} \mathrm{C}$ and $167.4 \mu \mathrm{S}$ $\mathrm{cm}^{-1}$, respectively. The lake was slightly alkaline $(7.5 \pm 0.1)$ and showed no clear change in $\mathrm{pH}$ within the water column. Previously published water properties where C. sowerbii medusae were found to be similar are summarised in Table 1 \& Table S1 in Supplement 2 at www.int-res.com/articles/suppl/b030 p069_supp2.xlsx. To report these data, the literature was searched specifically for environmental parameters at the time of medusa bloom (see Sections 2.5. and 3.5.).

\subsection{Observational record of $C$. sowerbii in BC between 1990 and 2020}

C. sowerbii was observed in $\mathrm{BC}$ for the first time in 1990 and sporadically in the following 3 decades. The number of lake sites, until today, was rather limited (24 lakes), and engaged observers reported jellyfish sightings from the same water bodies over many years (Fig. 5). The vast majority of sightings 
Table 1. Major abiotic parameters in freshwater environments (lentic and lotic, $\mathrm{n}=118$ ) at or near the surface with Craspedacusta sowerbii collected in the uppermost $6 \mathrm{~m}$ of the water column (in most cases shallower than this, $\mathrm{n}=37$ ). Months of occurrence in Northern and Southern Hemispheres are indicated. A literature survey in Web of Science and Google Scholar formed the basis for the summarised data (for details see Table S1)

\begin{tabular}{|c|c|c|c|c|c|c|}
\hline Parameter & Unit & Mean & $\mathrm{SD}$ & Median & Range & $\begin{array}{c}\text { No. of } \\
\text { study sites }\end{array}$ \\
\hline Temperature & ${ }^{\circ} \mathrm{C}$ & 23.8 & 3.8 & 24.3 & $15.4-30.7$ & 83 \\
\hline $\mathrm{pH}$ & & 7.7 & 0.7 & 7.6 & $6.0-9.1$ & 50 \\
\hline Dissolved oxygen concentration & $\mathrm{mg} \mathrm{l}^{-1}$ & 7.9 & 1.5 & 8.1 & $3.5-11.1$ & 43 \\
\hline Secchi depth & $\mathrm{m}$ & 3.5 & 2.9 & 3.1 & $0.2-14.5$ & 38 \\
\hline Conductivity at $20^{\circ} \mathrm{C}$ & $\mu \mathrm{S} \mathrm{cm} \mathrm{cm}^{-1}$ & 143.5 & 151.8 & 64.5 & $1.0-490.0$ & 22 \\
\hline Chlorophyll a concentration & $\mu \mathrm{g} \mathrm{l}^{-1}$ & 9.5 & 18.4 & 3.6 & $1.2-75.0$ & 18 \\
\hline Months (Northern Hemisphere) & & & & & May-Dec & 88 \\
\hline Months (Southern Hemisphere) & & & & & Dec-Aug & 30 \\
\hline
\end{tabular}

occurred in western and southern BC regions, where most of the largest cities are located and the climate is the mildest. Over the course of 3 decades, an exponential increase in sightings has been observed (Fig. 6A). No polyps have been recorded from BC freshwater systems. Jellyfish occurrences in Florence Lake, Glen Lake, and Killarney Lake (all near Victoria) have been reported most frequently. Anecdotal evidence exists to suggest the presence of C. sowerbii on southern Vancouver Island dating back to the late 1940s and early 1950s (D. Hutchinson pers. comm.) and on the Sunshine Coast between the late 1980s and early 1990s (M. Fearn pers. comm.).

\subsection{Literature review}

As of May 2021, a total of 209 studies had been published on C. sowerbii (Fig. 6B). It is worth mentioning that single notes on the occurrence of this hydrozoan species were published before 1901 (the beginning of the considered period). Between 19311940 and 1991-2000, on average 17 studies were published per decade, with no down- or upward trend. Most of these publications were short observational notes mentioning the species' first occurrence or range expansion into non-native habitats. The number of primary literature articles on medusae was, at all times, 1.5-14 times higher than the number of studies dedicated to polyps. Despite the continuation and numerical increase in descriptive observational studies, the number of biological, ecological, and taxonomic studies increased in 20012010 and 2011-2020 to a total of 34 and 46 studies decade $^{-1}$, respectively (Fig. 6B). Since the beginning of 2021, only 3 studies have been published, and it remains to be seen whether this numerical upward trend, reflecting increased distribution range and growing scientific interest, will continue. This literature survey formed the basis of the formulation of knowledge gaps in Craspedacusta research that is outlined in the next section.

\section{DISCUSSION}

\subsection{Craspedacusta in Canada and other high-latitude habitats}

Only a few records of Craspedacusta sowerbii exist in the Americas north of the $48^{\text {th }}$ parallel (2 lakes in McAlpine et al. 2002 and 2 lakes in El Moussaoui \& Beisner 2017b). Nevertheless, sighting locations in Sweden, Finland, and central Siberia are situated further north (Väinölä 2002, Lundberg et al. 2005, Stepanjants et al. 2009). As temperature plays a critical role in the polyp's medusa budding (FolinoRorem et al. 2016) and subsequent growth in the water column, blooming of $C$. sowerbii medusae has often been restricted to shallow and protected sites or freshwater systems with limited circulation. Such conditions are most often found between May and December in the Northern Hemisphere (Table 1), despite large latitudinal differences. In British Columbia (BC), jellyfish observations occurred between July and October, but most frequently in August and September, namely in late summer when freshwater systems had sufficient time to warm up. Environmental envelopes for $\mathrm{pH}$, chl $\mathrm{a}$, dissolved oxygen concentrations and other parameters are relatively broad (see Tables 1 \& S1 for references) and may not be suitable for predicting medusa occurrence at a global scale; however, they underline the high plasticity of the medusa and likely polyp stages. 

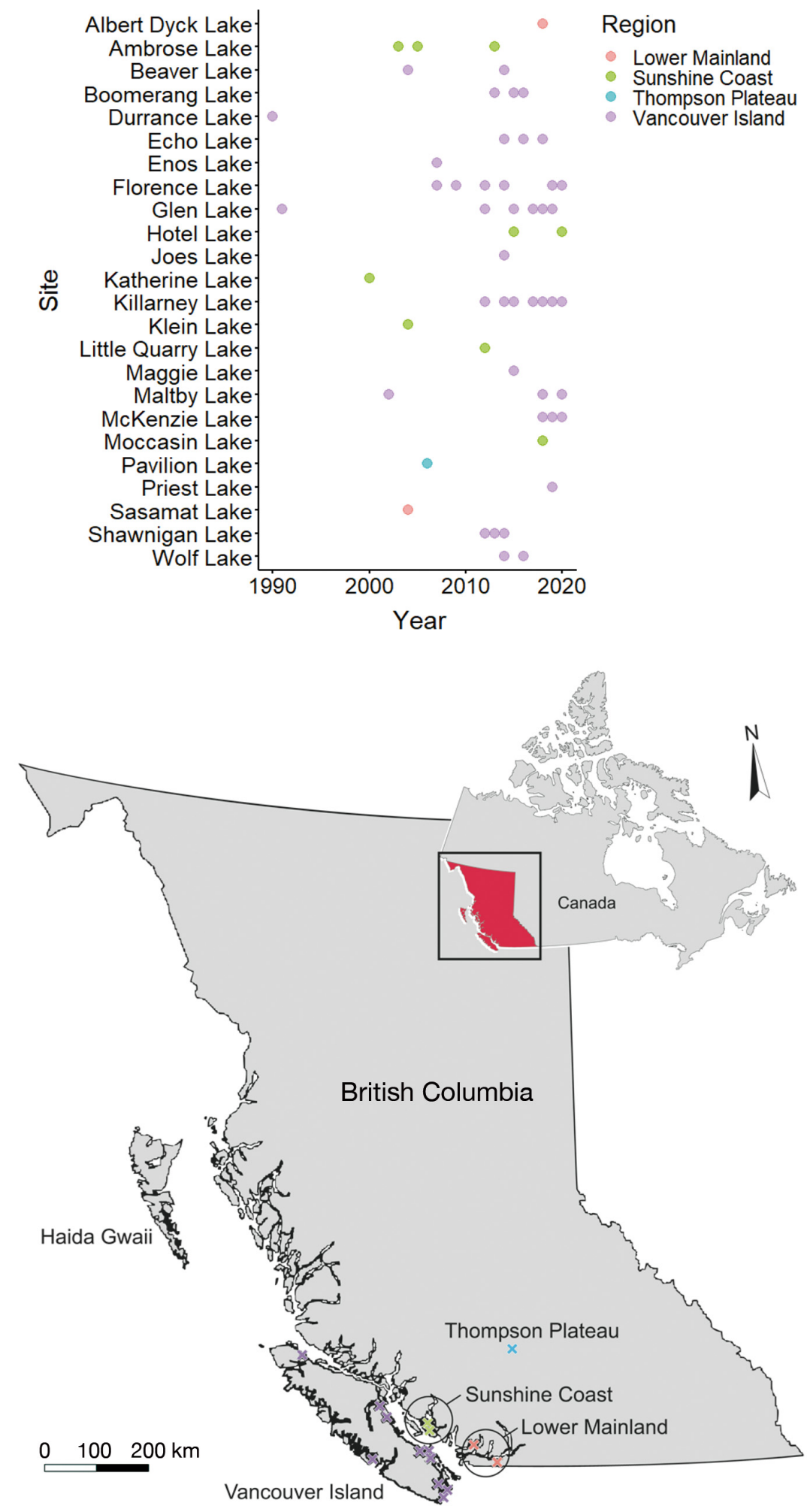

Fig. 5. Sightings of Craspedacusta sp. in British Columbia, Canada (1990-2020). Upper panel: observations per site over time; lower panel: locations of lakes. Due to considerable overlap, some closely neighbouring sites are represented by only one cross. Source: http://freshwaterjellyfish.org/ (accessed March 2020) by Terry L. Peard; data provided by Heidi Gartner

(Royal British Columbia Museum) and community science approach
The community science approach in this study allowed us, in conjunction with reports from the personal website of T. Peard, to document for the first time that $C$. sowerbii is more common in western and southern BC than believed earlier, highlighting the value of an engagement of the broader public. These regions are also the areas with the highest human population and the mildest weather year-round. The considerable increase in freshwater jellyfish sightings between 2011 and 2020 on the one hand may be indicative of an increase in the distributional range and frequency of blooms, but on the other hand, may be a result of increased observational effort in recent years (Minchin et al. 2016), also facilitated by the outreach efforts of this study. An increase in distribution and blooming frequency detected by citizen observations could indeed be explained by increasingly favourable conditions for polyp budding of medusae and growth due to climate warming and accelerated transport of stress-resistant podocysts among lakes (Schifani et al. 2019). However, at present, there are no quantitative data available supporting one or the other explanation. Environmental monitoring using state of the art genetic methods such as sampling for environmental DNA have proven to be useful in mapping the distribution of C. sowerbii in southern Ontario (Mychek-Londer et al. 2020). Despite this being a qualitative presence-absence measure, it is currently still not possible to quantify the signal and discriminate whether only one or several life cycle stages can be detected.

The first confirmed jellyfish observation originates from Durrance Lake, in close vicinity to Killarney Lake, in August 1990 (Corry 1994). The author highlighted the phenomenon that in most cases, C. sowerbii medusa populations are unisexual and may originate from a single polyp (either male or female) that reproduced asexually 

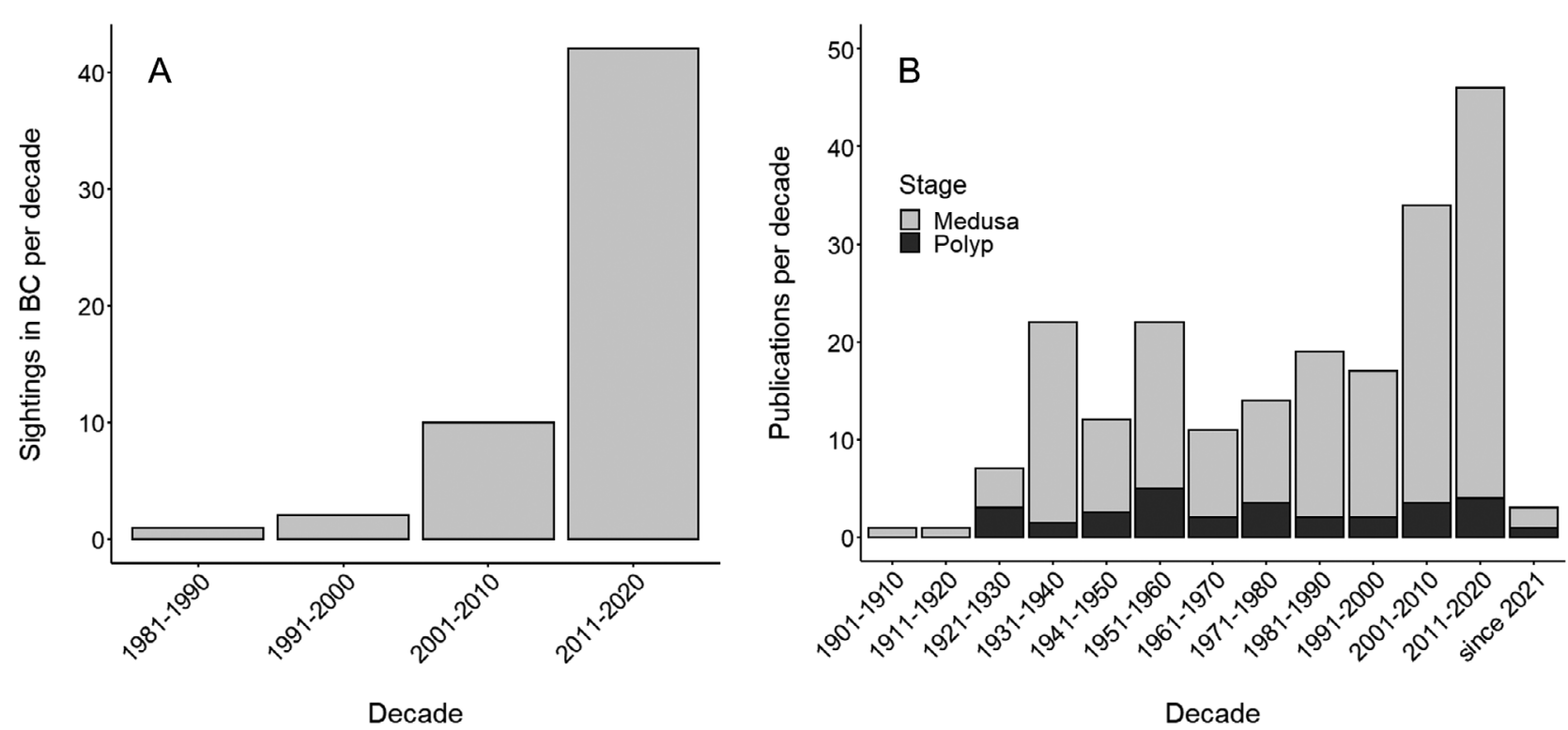

Fig. 6. (A) Decadal number of Craspedacusta sowerbii sightings in British Columbian (BC) freshwater systems based on records in Fig. $3(n=55)$. Sightings are only recorded once per site and year. No polyps have been reported from BC freshwater systems yet. (B) Decadal number of primary papers on C. sowerbii distribution, biology, ecology, and systematics worldwide $(\mathrm{n}=209)$. The life cycle stage in focus (i.e. medusa or polyp) is indicated

and founded the cloned population. In Durrance Lake in 1990, the medusa population seemed to consist of male individuals. On the contrary, Wiggins et al. (1957) described medusa populations from 3 lakes in Ontario that consisted of only female individuals. Only 22 specimens (all with developing male gametes) with an average diameter of about $10 \mathrm{~mm}$ were collected in the present study.

\subsection{Morphological and phylogenetic remarks on BC's Craspedacusta}

From a morphological point of view, the specimens collected in Killarney Lake agree with those characters described by Jankowski (2001) for C. sowerbii. Usable information from nematocyst measurements seems to be quite incomplete and controversial. Jankowski (2001) compiled information from Dejdar (1934), giving quite similar data (16-19 $\mu \mathrm{m}$ in length, 6.5-8.0 $\mu \mathrm{m}$ in width); however, the former author reported these measurements for medusae, while Dejdar informed these data for polyps, mentioning that the nematocysts of the medusa are much smaller, about half in size than those of the polyps. The mean and size range from $\mathrm{BC}$ medusae are close to half of the dimensions under debate (close to observations by Dejdar 1934). Dejdar's anatomical and nematocyst information are from some medusae collected in Vltava (Moldau close to Libčice, Czech
Republic). However, BC specimens of C. sowerbii are quite similar to those examined by Oualid et al. (2019) from North Africa, but both sets of samples are, from a phylogenetic point of view (mitochondrial and nuclear markers), widely separated clades (Figs. 4, S1 \& S2), sometimes separated by different Craspedacusta species (Fig. S2).

In agreement with Oualid et al. (2019), 16S and ITS analyses showed at least 4 main Craspedacusta lineages. According to the identification provided by the different authors to the sequences used (Zhang et al. 2009, Zou et al. 2012), these species are C. sinensis (for the moment only reported from China), C. ziguiensis (only from China), and 2 separate widespread lineages mainly attributed to $C$. sowerbii (Collins et al. 2008, Fritz et al. 2009, Zhang et al. 2009, Stefani et al. 2010, Zou et al. 2012, Karaouzas et al. 2015, Failla Siquier et al. 2017, Riyas \& Kumar 2017, Fuentes et al. 2019, Oualid et al. 2019). The divergent Cox1 sequence MF000493 from Switzerland could be incorrect - perhaps a nuclear pseudogene, as the $16 \mathrm{~S}$ sequence places it within one of the 2 main $C$. sowerbii clades (P. Schuchert pers. comm.). More complete molecular information is desirable from central Europe, where (apart from China) both main clades are present in close proximity.

Although unfortunately the molecular coverage is not complete (16S-Cox1-ITS) in all sequenced specimens, both $C$. sowerbii main lineages are present in China plus some countries of the old and new worlds 
(the first, just in the order of discussion here, not necessarily in the order of dispersal), or just present in the old world (the second main lineage discussed here). Apart from China, the first main lineage (because not all specimens are the identical haplotypes) is widespread, being detected in Canada/BC, Eastern USA, Uruguay, Chile, and South Italy (Sicily), taking into consideration the lack of some markers, while the second main lineage has been detected (for the moment) in North Africa and central Europe. Schifani et al. (2019) used the binomen C. sowerbii for the widely distributed (China, old and new worlds) first main lineage listed here, and C. kiatingi for that present in China and central Europe. However, the morphological variability described for $C$. sowerbii and the close species (or varieties) $C$. kiatingi and C. kawaii overlaps (e.g. Oka 1906, Kramp 1950, Jankowski 2001).

Indeed, BC specimens would be considered C. sowerbii; even the number of nematocysts per wart on the tentacles agree with the range indicated by Jankowski (2001). However, this lineage was detected in southern Europe, and C. sowerbii was described based on a population from northern Europe (England), where $C$. kiatingi has also been assumed to be the correct name. We believe that the last word on this issue is pending a more global morphological and molecular comparison, as well as the molecular characterisation of putative localities from the south of England. Paradoxically, the aquatic plants in the tanks where $C$. sowerbii was discovered came from South America. Thus, one is tempted to ask whether the American (also present in Southern Europe and China) lineage is the putative source of importation of the original material examined by Lankester? Furthermore, the validity of the use of the previously proposed names must be corroborated. The placement of Greek, Swiss, and Indian sequenced individuals remains controversial (Fig. 4), requiring additional marker sequencing and complete concatenated analyses. Thus, C. sowerbii can be considered a species complex-at least 2 distant genetic lineages with similar morphological features. A more complete sampling programme, detailed morphological descriptions, and genetic analyses are highly recommended for the $C$. sowerbii species complex, as also stressed by Oualid et al. (2019). These further efforts should permit the better delineation of species (firstly by genetics), allowing differentiation among those morphological characters with reliable value in the delimitation of species, and future separate additional ecological and physiological investigations.

\subsection{Future research directions}

Despite a considerable body of publications on $C$. sowerbii (Fig. 6B), research has mostly been sporadic and opportunistic. The number of ecological studies on this non-indigenous species is very lucid. The numerical succession of publications on Craspedacusta biology, ecology, distribution, and systematics is shown in Fig. 6B. Even though it is likely that most literature was included, some articles (probably mostly early studies) may have been overlooked. However, the general trend may be real. Many open questions remain unanswered, and below we list some main goals that we believe should be addressed in the future to better understand the biology and ecological impact of this species.

- One of the first research tasks to be addressed is trying to assign a reliable scientific name to each one of the 2 main lineages that currently exist under the name $C$. sowerbii (partially discussed by Fritz et al. 2009, Schifani et al. 2019, and Oualid et al. 2019). Both lineages, if not more, are clearly identifiable by genetics. The type material of this species is from London (Lankester 1880a,b). Thus, special efforts should be made in nearby areas to clarify the closer haplotypes that can be considered C. sowerbii, and then a detailed morphological description of that population should be made. This may be the starting point in the search for an available or new name (according to ICZN 1999) for the other main lineage, today still also known as $C$. sowerbii.

- In some cases, the surface abundance of C. sowerbii has been based on onshore or boat observations (e.g. Jankowski 2004, Schifani et al. 2019). Quantitative estimates based on net tows are rare. One easily approachable goal should be the quantification of abundances (polyp and medusa stages) in deeper parts of lentic and lotic ecosystems. Sampling for environmental DNA would make the monitoring of many more sites possible, as has been the case in the past (e.g. Mychek-Londer et al. 2020).

- Until today, there have only been a few studies dedicated to examining the elemental composition and organic content of C. sowerbii (e.g. Ludwig 1977, Jankowski 2000). This kind of information is, however, critical for the determination of volumespecific biomass data. Understanding the temporal succession of biomass could not only be utilised in growth rate measurements (e.g. Folino-Rorem et al. 2016, Marchessaux \& Bejean 2020b), but would also be important for pelagic life span estimation (e.g. 
Lewis et al. 2012, Folino-Rorem et al. 2016), which still shows enormous variability among locations.

- Knowledge on the trophic ecology of C. sowerbii originates exclusively from in situ observations and laboratory and mesocosm experiments (e.g. Jankowski et al. 2005, Smith \& Alexander 2008, Marchessaux \& Bejean 2020b). At the completion of the present article, no studies describing feeding interactions using biomarkers such as stable isotopes or fatty acids had been conducted. We encourage measurement/determination of energy contents to describe $C$. sowerbii's value as a prey item more appropriately and to parameterise more realistically future food web models. All information will be vital for the evaluation of freshwater jellyfish predation impacts and ecosystem interactions.

- In the past, there have been controversial reports on positive phototaxis and diel vertical migrations of C. sowerbii (e.g. Acker \& Muscat 1976, Spadinger \& Maier 1999). While migratory behaviour may differ among study sites and populations, there are only a few observations on light-induced vertical distribution changes beyond superficial onboard observations. More research dedicated to these vertical biomass movements that may influence trophic interactions is urgently needed.

- Similar to relatives in the marine realm, very limited information exists on the distribution of benthic polyp beds in natural habitats. Bottom scraping has been used a number of times to detect polyps, but currently there is a paucity of any data on this critical life cycle stage. Furthermore, abiotic factors that trigger budding of medusae by polyps and tolerance to e.g. bottom water anoxia are poorly studied. Symbiotic relationships as well as competition and predation have been described in some studies (e.g. Ludwig et al. 1979, Stanković \& Ternjej 2010, Morpurgo et al. 2021), but much remains unknown for C. sowerbii.

- One of the biggest mysteries of this invasive medusa is its often unisexual populations. Several hypotheses have been proposed in the past addressing this unusual phenomenon (e.g. Pennak 1956, Corry 1994), but until now none of them has been critically examined. The explanation for this evolutionary unsustainable and annually reoccurring phenomenon still requires discovery.

Acknowledgements. We thank Alisha Brown, who reported the first medusae in Killarney Lake and thus enabled us to start this investigation, Robert W. Izett for help during the field sampling, and Bernd Lüskow for creating the map. We thank all volunteers who contributed their observations to the distribution range characterisation of $C$. sowerbii. We also thank Elizabeth M. Corry, Heidi Gartner, Terry L. Peard, and 3 anonymous reviewers for fruitful discussions and constructive comments made on an earlier version of the manuscript. F.L. was supported by an IDF scholarship granted by the University of British Columbia and the NSERC Discovery Grant RGPIN-2014-05107 held by E.A.P.

\section{LITERATURE CITED}

Acker TS, Muscat AM (1976) The ecology of Craspedacusta sowerbii Lankester, a freshwater hydrozoan. Am Midl Nat 95:323-336

Boothroyd IKG, Etheredge MK, Green JD (2002) Spatial distribution, size structure, and prey of Craspedacusta sowerbyi Lankester in a shallow New Zealand lake. Hydrobiologia 468:23-32

* Bose APH, Zimmermann H, Sefc KM (2019) Freshwater hydrozoan blooms alter activity and behaviour of territorial cichlids in Lake Tanganyika. $\mathrm{R}$ Soc Open Sci 6: 191053

Bouillon J, Boero F (2000) Synopsis of the families and genera of the Hydromedusae of the world, with a list of the worldwide species. Thalass Salentina 24:1-250

* Braet F, de Zanger R, Wisse E (1997) Drying cells for SEM, AFM and TEM by hexamethyldisilazane: a study on hepatic endothelial cells. J Microsc 186:84-87

Bridge D, Cunningham CW, DeSalle R, Buss LW (1995) Class-level relationships in the Phylum Cnidaria: molecular and morphological evidence. Mol Biol Evol 12: 679-689

* Collins AG, Bentlage B, Lindner A, Lindsay D and others (2008) Phylogenetics of Trachylina (Cnidaria: Hydrozoa) with new insights on the evolution of some problematical taxa. J Mar Biol Assoc UK 88:1673-1685

Corry EM (1994) Freshwater jellyfish collected locally. Vic Nat 50:7

* Davis CC (1955) Notes on the food of Craspedacusta sowerbii in Crystal Lake, Ravenna, Ohio. Ecology 36:364-366

* Dejdar E (1934) Die Süßwassermeduse Craspedacusta sowerbii Lankester in monographischer Darstellung. Z Morphol Oekol Tiere 28:595-691

*Dendy JS (1978) Polyps of Craspedacusta sowerbyi as predators on young striped bass. Prog Fish-Cult 40:5-6

* Dodson SI, Cooper SD (1983) Trophic relationships of the freshwater jellyfish Craspedacusta sowerbyi Lankester 1880. Limnol Oceanogr 28:345-351

* Duggan IC, Eastwood KR (2012) Detection and distribution of Craspedacusta sowerbii: observations of medusae are not enough. Aquat Invasions 7:271-275

* Dumont HJ (1994) The distribution and ecology of the freshand brackish-water medusae of the world. Hydrobiologia 272:1-12

El Moussaoui N, Beisner BE (2017a) La méduse d'eau douce Craspedacusta sowerbii: Espèce exotique répandue dans les lacs du Québec. Nat Can 141:40-46

El Moussaoui N, Beisner BE (2017b) Facteurs environnementaux associés à la prolifération de la méduse d'eau douce Craspedacusta sowerbii dans les lacs du Québec. Nat Can 141:47-57

F Failla Siquier MG, Serra Alanis WS, Debat CM (2017) First record of Craspedacusta sowerbii Lankester, 1880 (Hydrozoa, Limnomedusae) in a natural freshwater lagoon of Uruguay, with notes on polyp stage in captivity. Braz J Biol 77:665-672 
Fantham HB, Porter A (1938) Occurrence of the freshwater medusa, Craspedacusta sowerbii, in Eastern Canada. Nature 141:515-516

Felsenstein J (1985) Confidence limits on phylogenies: an approach using the bootstrap. Evolution 39:783-791

Folino-Rorem NC, Reid M, Peard TL (2016) Culturing the freshwater hydromedusa, Craspedacusta sowerbii under controlled laboratory conditions. Invertebr Reprod Dev 60:17-27

Fritz GB, Schill RO, Pfannkuchen M, Brümmer F (2007) The freshwater jellyfish Craspedacusta sowerbii Lankester, 1880 (Limnomedusa: Olindiidae) in Germany, with a brief note on its nomenclature. J Limnol 66:54-59

Fritz GB, Pfannkuchen M, Reuner A, Schill RO, Brümmer F (2009) Craspedacusta sowerbii, Lankester 1880 - population dispersal analysis using COI and ITS sequences. J Limnol 68:46-52

Fuentes RA, Cárdenas L, Abarzua A, Caputo L (2019) Southward invasion of Craspedacusta sowerbii across mesotrophic lakes in Chile: geographical distribution and genetic diversity of the medusa phase. Freshw Sci 38:193-202

* Godknecht A, Tardent P (1988) Discharge and mode of action of the tentacular nematocysts of Anemonia sulcata (Anthozoa: Cnidaria). Mar Biol 100:83-92

Huelsenbeck JP, Ronquist F (2001) MRBAYES: Bayesian inference of phylogenetic trees. Bioinformatics 17:754-755

ICZN (International Commission on Zoological Nomenclature) (1999) International code of zoological nomenclature, $4^{\text {th }}$ edn. International Trust for Zoological Nomenclature, London

Jankowski T (2000) Chemical composition and biomass parameters of a population of Craspedacusta sowerbii Lank 1880 (Cnidaria: Limnomedusa). J Plankton Res 22:1329-1340

Jankowski T (2001) The freshwater medusae of the world a taxonomic and systematic literature study with some remarks on other inland water jellyfish. Hydrobiologia 462:91-113

Jankowski T (2004) Predation of freshwater jellyfish on Bosmina: the consequences for population dynamics, body size, and morphology. Hydrobiologia 530-531: 521-528

Jankowski T, Anokhin B (2019) Phylum Cnidaria. In: Rogers DC, Thorp JH (eds) Thorp and Covich's freshwater invertebrates, $4^{\text {th }}$ edn. Elsevier, London, p 93-111

Jankowski T, Ratte HT (2000) On the influence of the freshwater jellyfish Craspedacusta sowerbii on the zooplankton community. Int Ver Theor Angew Limnol: Verh $27: 3287-3290$

Jankowski T, Strauss T, Ratte HT (2005) Trophic interactions of the freshwater jellyfish Craspedacusta sowerbii. J Plankton Res 27:811-823

Jankowski T, Collins AG, Campbell R (2008) Global diversity of inland water cnidarians. Hydrobiologia 595:35-40

Karaouzas I, Zogaris S, Lopes-Lima M, Froufe E, Varandas S, Teixeira A, Sousa R (2015) First record of the freshwater jellyfish Craspedacusta sowerbii Lankester, 1880 in Greece suggests distinct European invasion events. Limnology 16:171-177

Kimura M (1980) A simple method for estimating evolutionary rates of base substitutions through comparative studies of nucleotide sequences. J Mol Evol 16:111-120

Kramp PL (1950) Freshwater medusae in China. Proc Zool Soc Lond 120:165-184
Lamb PD, Hunter E, Pinnegar JK, Doyle TK, Creer S, Taylor MI (2019) Inclusion of jellyfish in 30+ years of Ecopath with Ecosim models. ICES J Mar Sci 76:1941-1950

KLankester ER (1880a) On a new jelly-fish of the order Trachomedusae, living in fresh water. Nature 22:147-148

Lankester ER (1880b) On Limnocodium (Craspedacusta) sowerbii, a new trachomedusa inhabiting freshwater. Q J Microsc Sci 20:351-371

K Lewis C, Migita M, Hashimoto H, Collins AG (2012) On the occurrence of freshwater jellyfish in Japan 1928-2011: eighty-three years of records of Mamizu kurage (Limnomedusae, Olindiidae). Proc Biol Soc Wash 125: 165-179

Ludwig HW (1977) 99.26 per cent water content in the freshwater medusa Craspedacusta sowerbii. Z Naturforsch 32:1011-1012

Ludwig HW, Becker N, Rambow C (1979) Die Süßwassermeduse Craspedacusta sowerbii (Hydrozoa: Limnomedusae) im Rhein-Neckar-Gebiet. Beitr naturk Forsch Südw Dtl 38:141-153

Lundberg S, Svensson JE, Petrusek A (2005) Craspedacusta invasions in Sweden. Int Ver Theor Angew Limnol: Verh 29:899-902

Marchessaux G, Bejean M (2020a) From frustules to medusae: a new culture system for the study of the invasive hydrozoan Craspedacusta sowerbii in the laboratory. Invertebr Biol 139:e12308

Marchessaux G, Bejean M (2020b) Growth and ingestion rates of the freshwater jellyfish Craspedacusta sowerbii. J Plankton Res 42:783-786

* McAlpine DF, Peard TL, Fletcher TJ, Hanson G (2002) First reports of the freshwater jellyfish Craspedacusta sowerbyi (Hydrozoa: Olindiidae) from maritime Canada with a review of Canadian occurrences. J Freshwat Ecol 17: 341-344

Meyer CP, Geller JB, Paulay G (2005) Fine scale endemism on coral reefs: archipelagic differentiation in turbinid gastropods. Evolution 59:113-125

* Minchin D, Caffrey JM, Haberlin D, Germaine D, Walsh C, Boelens R, Doyle TK (2016) First observations of the freshwater jellyfish Craspedacusta sowerbii Lankester, 1880 in Ireland coincides with unusually high water temperatures. BioInvasions Rec 5:67-74

Moreno-Leon MA, Ortega-Rubio A (2009) First record of Craspedacusta sowerbyi Lankester, 1880 (Cnidaria: Limnomedusae: Olindiidae) in Mexico (Adolfo Lopez Mateos reservoir), with notes on their feeding habits and limnological dates. Biol Invas 11:1827-1834

Morpurgo M, Alber R (2015) First record of the freshwater jellyfish Craspedacusta sowerbii Lankester, 1880 (Cnidaria: Hydrozoa: Limnomedusae) in South Tyrol (Italy). Gredleriana 15:61-64

Morpurgo M, Schuchert P, Vorhauser S, Alber R (2021) Occurrence of two distinct lineages of the freshwater jellyfish Craspedacusta sowerbii (Hydrozoa: Limnomedusae) in Italy. J Limnol 80:1974

Mychek-Londer JG, Balasingham KD, Heath DD (2020) Using environmental DNA metabarcoding to map invasive and native invertebrates in two Great Lakes tributaries. Env DNA 2:283-297

Nation JL (1983) A new method using hexamethyldisilazane for preparation of soft insect tissues for scanning electron microscopy. Stain Technol 58:347-351

Nei M, Kumar S (2000) Molecular evolution and phylogenetics. Oxford University Press, New York, NY 
Odorico DM, Miller DJ (1997) Variation in the ribosomal internal transcribed spacers and 5.8S rDNA among five species of Acropora (Cnidaria; Scleractinia): patterns of variation consistent with reticulate evolution. Mol Biol Evol 14:465-473

Oka A (1906) Eine neue Süsswassermeduse aus China. Annot Zool Jpn 6:220-227

Oualid JA, Iazza B, Tamsouri NM, El Aamri F, Moukrim A, López-González PJ (2019) Hidden diversity under morphology-based identifications of widespread invasive species: the case of the 'well-known' hydromedusa Craspedacusta sowerbii Lankester 1880. Anim Biodivers Conserv 42:301-316

Pennak RW (1956) The fresh-water jellyfish Craspedacusta in Colorado with some remarks on its ecology and morphological degeneration. Trans Am Microsc Soc 75 : 324-331

Pérez-Bote JL, Muñoz A, Morán R, Roso R, Romero AJ (2006) First record of Craspedacusta sowerbyi Lankester, 1880 (Cnidaria: Limnomedusae: Olindiidae) in the Proserpina Reservoir (Extremadura, SW Spain) with notes on their feeding habits. Belg J Zool 136:163-166

Reisinger E (1957) Zur Entwicklungsgeschichte und Entwicklungsmechanik von Craspedacusta (Hydrozoa, Limnotrachylina). Z Morphol Oekol Tiere 45:656-698

Riyas A, Kumar AB (2017) Record of freshwater jellyfish blooms of invasive Craspedacusta sowerbii Lankester, 1880 (Hydrozoa, Limnomedusae) from Kerala, India. J Aqua Biol Fisheries 5:154-159

Ronquist F, Huelsenbeck JP (2003) MRBAYES 3: Bayesian phylogenetic inference under mixed models. Bioinformatics 19:1572-1574

Schifani E, Viviano A, Viviano R, Naselli-Flores L, Marrone F (2019) Different lineages of freshwater jellyfishes (Cnidaria, Olindiidae, Craspedacusta) invading Europe: another piece of the puzzle from Sicily, Italy. Limnology 20:143-151

Shively S, Miller WR (2009) The use of HMDS (hexamethyldisilazane) to replace critical point drying (CPD) in the preparation of tardigrades for SEM (scanning electron microscope) imaging. Trans Kans Acad Sci 112:198-200

Smith AS, Alexander JE Jr (2008) Potential effects of the freshwater jellyfish Craspedacusta sowerbii on zooplankton community abundance. J Plankton Res 30:1323-1327

Spadinger R, Maier G (1999) Prey selection and diel feeding of the freshwater jellyfish, Craspedacusta sowerbyi.

Editorial responsibility: Victor Benno Meyer-Rochow Oulu, Finland

Reviewed by: 3 anonymous referees
Freshw Biol 41:567-573

* Stanković I, Ternjej I (2010) New ecological insight on two invasive species: Craspedacusta sowerbii (Coelenterata: Limnomedusae) and Dreissenia polymorpha (Bivalvia: Dreissenidae). J Nat Hist 44:2707-2713

Stefani F, Leoni B, Marieni A, Garibaldi L (2010) A new record of Craspedacusta sowerbii, Lankester 1880 (Cnidaria, Limnomedusae) in Northern Italy. J Limnol 69:189-192

Stepanjants SD, Timoshkin OA, Arov IV (2009) The first finding of Craspedacusta medusae (Cnidaria, Medusozoa, Hydrozoa, Limnomedusae, Olindiidae) in watershed basin of Lake Baikal. Zool Zh 88:239-242

Tamura K (1992) Estimation of the number of nucleotide substitutions when there are strong transition-transversion and $\mathrm{G}+\mathrm{C}$-content biases. Mol Biol Evol 9:678-687

* Tamura K, Stecher G, Peterson D, Filipski A, Kumar S (2013) MEGA6: molecular evolutionary genetics analysis version 6.0. Mol Biol Evol 30:2725-2729

Thomas IM (1951) Craspedacusta sowerbyi in South Australia, with some notes on its habits. Trans R Soc S Aust 74:59-65

Ungstad A (2012) Secret lakes of southern Vancouver Island. Ungstad Information Architects, Geneva

Väinölä R (2002) The freshwater jellyfish Craspedacusta sowerbii in Finland. Memoranda Soc Fauna Flora Fennica 78:13-15

* Viosca P Jr, Burkenroad MD (1936) The fresh-water medusa in Louisiana. Science 84:155-156

Wesenberg-Lund C (1939) Biologie der Süßwassertiere. Springer Verlag, Vienna

Wiggins GB, Whitfield RE, Walden FA (1957) Notes on freshwater jellyfish in Ontario. Contributions of the Royal Ontario Museum No. 45. Royal Ontario Museum, Toronto

Zhang LQ, Wang GTQ, Yao WJ, Li WX, Gao Q (2009) Molecular systematics of medusae in the genus Craspedacusta (Cnidaria: Hydrozoa: Limnomedusae) in China with the reference to the identity of species. J Plankton Res 31:563-570

Ziser SW, Burke WW III (1984) A new record of the freshwater jellyfish Craspedacusta sowerbii Lankester in Louisiana. Proc LA Acad Sci 47:45-47

Zou H, Zhang J, Li W, Wu S, Wang G (2012) Mitochondrial genome of the freshwater jellyfish Craspedacusta sowerbyi and phylogenetics of Medusozoa. PLOS ONE $7: \mathrm{e} 51465$

Submitted: January 7, 2021

Accepted: February 25, 2021

Proofs received from author(s): May 10, 2021 